Монгол улс ОХУ-ын хооронд дипломат харилцаа тогтсоны 90 жилийн ойд зориулав

\title{
ОРОСЫН ДИПЛОМАТ АЛБА
}

П.Мягмардорж*

Аливаа улсын гадаад бодлого нь тодорхой бодит нөхцлүүдээс хамааран бүрэлдэн бий болдог. Тухайлбал, түүхэн хөгжил, газарзүйн байршил, улс төр, эдийн засаг, соёл, шашин гэх мэт. Эдгээрийн үндсэн дээр улсуудын үндэсний ашиг сонирхол тогтож байдаг бөгөөд олон улсын харилцааны нөхцөл байдал, агуулга өөрчлөгдөхийн хэрээр улс гүрний гадаад бодлогын өнгө аяс хувирч, шинэчлэгдэж байдаг. Гэвч үндэстэн улсын гадаад бодлогын залгамж шинж чанар хадгалагдан, олон зууны турш өөрийн онцлог байдлыг хадгалсаар байдаг. Үүний тод жишээ нь Оросын гадаад бодлого, дипломат ажиллагааны үүсэл, түүхэн хөгжил, түүний чиглэл, бүтэц зохион байгуулалт зэрэг юм. Оросын хаадын нэг нь “Орос орон бол үндэстэн улс бус дэлхийн нэг хэсэг” хэмээн тодорхойлсон нь Оросын газарзүйн болон соёл иргэншлүүдийн огтлолцол дахь байршлын онцлогийг давхар харуулж байна.

Орос улс нь гадаад бодлогоо тогтвортой, дипломат ажиллагаагаа улс гүрнийхээ ашиг сонирхолд нийцүүлэн явуулж ирсэн баялаг түүхтэй бөгөөд олон улсын харилцааны тодорхой үеүдэд өөрийн үндэсний ашиг сонирхлыг олон улсын тавцанд хамгаалан авч үлдэж чадсан юм. Түүнчлэн Оросын гадаад бодлого системчлэгдсэн, прагматик шинжтэй байдаг ба гадаад бодлого дипломат ажиллагаа нь шаардлагатай үед геостратегийн тэнцвэртэй байдлыг хангасан байдаг.

Өнөөгийн Оросын Холбооны Улсын дипломат алба нь өндөр мэдлэг, ур чадвар бүхий мэргэшсэн дипломат ажилтан, албан хаагчдыг эгнээндээ багтаасан өргөн сүлжээ бүхий дэлхийн томоохон дипломат албадын нэг болж чадсан ба энэхүү Оросын дипломат албаны бүтэц, зохион байгуулалт бий болоход өмнөх үеийн Оросын дипломат ажиллагаа болон дипломат алба ихээхэн нөлөө үзүүлсэн билээ.

\section{Оросын дипломат албаны түух}

9-13-р зууны үед Эртний Орос өөрийн төрт улсыг үүсгэн байгуулж, олон улсын харилцаанд идэвхитэй оролцох болсноор зүүн Европт Карпатаас Уралын нуруу хүртэлх, 
Хар тэнгисээс Ладож нуур болон Балтийн тэнгис хүртэлх орон зайд улс төрийн газарзүй болоход чухал нөлөө үзүүлжээ.

Византын эзэнт гүрэнтэй холбоо тогтоохоор 838 онд Оросын элчийг Константинопольд заран явуулсан нь Оросын дипломат ажиллагааны анхны алхмуудын нэг болж 860 онд Византын эзэнт гүрэнтэй тогтоосон “Энх тайвны тухай гэрээ” нь Оросыг олон улсын хэмжээнд хүлээн зөвшөөрсөн анхны тохиолдол байсан юм. Византын эзэнт гүрэнтэй харилцах харилцаа нь тухайн үеийн Оросын гадаад бодлогын гол чиглэл нь болж байв. 11-p зууны дунд үеэс Монголчуудын байлдан дагуулалт хүртэлх 200 гаруй жилийн хугацаанд Оросын феодалын задралын үе үргэлжилсэн бөгөөд нэгдсэн гадаад бодлого, дипломат ажиллагаа явуулах боломжгүй болжээ. Харин 15-р зууны үеэс Алтан Ордын улсын дарангуйлал дуусгавар болж, Москва төвтэй нэгдсэн Оросын төрт улс байгуулагдсанаар Оросын дипломат ажиллагаa, дипломат албаны үндэс суурь тавигджээ.

15-р зууны эцэс 16-р зууны эхэнд буюу III Иван хааны үед Оросын гадаад бодлого, дипломат ажиллагааны өмнө шийдвэрлэвэл зохих чухал асуудлууд гарч ирснээр бие даасан дипломат албыг бий болгох зайлшгүй шаардлага гарч иржээ. Анхлан гадаад улс төрийн бодлогын асуудлыг Боярын Думаар хэлэлцэн зохицуулж байсны зэрэгцээ гадаадад томилогдож байсан элчээр Москвад алба хашиж байсан гадаадын харъяат хүмүүсээс сонгон томилдог байв. Харин III Василий хааны үед орос хүмүүсийг томилох болсон байна.

1549 онд догшин Иван хаан гадаад хэргийн асуудлыг эрхлэн явуулах "Посольский приказ” -ыг байгуулж, тухайн үед өндөр боловсролтойд тооцогдож байсан Иван Михайлович Висковатыйг тухайн албыг хариуцсан түшмэлээр томилж, түүнд бүх элчин төлөөлөгчийн ажлыг хариуцуулжээ. ИйнхүҮ Оросын анхны гадаад бодлогын асуудал хариуцсан бие даасан байгууллага байгуулагджээ.

16-р зууны сүүлчээр энэ албанд 15-17 түшмэл, хэд хэдэн орчуулагчид ажиллаж “Посольский приказ” нь бүтцийн хувьд газарзүйн асуудал эрхлэсэн нэгжүүдэд хуваагдаж байлаа.

1570 онд Висковатыйг цаазлагдсаны дараа “Посольский приказ”-ыг удирдахаар ах дүҮ Щелкалов нар томилогдон ажилласан бол 17-р зууны нэгдүгээр хагаст дээрх байгууллагыг И.Т.Грамотин, 17-р зууны хоёрдугаар хагаст А.Л.Ордин-Нащокин, А.С.Матвеев, ван В.В.Голицын, Е.И.Украинцев нар тус тус удирдаж байжээ. Харин 17p зууны 50-70-аад оны үед “Посольский приказ" нь тодорхой бүтэц, зохион 
байгуулалттай болж ирсэн бөгөөд хэлтэс нэгжүүд нь тухайн нэгжийг толгойлж байсан түшмэдийн нэрээр нэрлэгдэж байгаад аажмаар 1, 2, 3, 4-р гэх мэт дугаарлагдах болсон. 17-р зууны 80-аад онд Европт боловсрол эзэмшсэн хүмүүс элчин сайдын яамны удирдлагад ирснээр тусгай хэлтэс албад нь тодорхой бүс нутгуудыг хариуцдаг болж энэ үед хөрш орнууд болох Шведэд 1634 онд, Польшид 1673 онуудад дипломат төлөөлөгчийн газар нээгдэж эдгээр нь 1699 он хүртэлх гадаад оронд байнга суух Оросын анхны дипломат төлөөлөгчийн газар болсон байна. 1699 онд Гаагад төлөөлөгчийн газраа нээсэн бол I Петр хааны үед Оросын хилийн чанад дахь төлөөлөгчийн газрын тоо эрчимтэйгээр нэмэгдэж, 1700 онд Дани, 1701 онд Австри, Турк, 1702 онд Франц, 1706 онд Их Британи болон Прусст тус тус дипломат төлөөлөгчийн газраа байгуулжээ.

18-р зууны эцэс гэхэд хилийн чанад дахь дипломат төлөөлөгчийн газрын тоо 21 болтлоо өссөн байна.

Үүний зэрэгцээ 16-р зууны эхэн үед Орост гадаадын консулын байгууллагууд үйл ажиллагаа явуулах болсноор Оросын консулын харилцаа өргөжиж эхэлсэний зэрэгцээ Оросын анхны консулын байгууллагууд Европт төдийгүй Азид байгуулагдаж эхэлсэн ажээ. Тухайлбал 1711 онд Венецид, 1715 онд Парист, 1719 онд Бээжинд, 1720 онд Шемахад, 1723 онд Бордод тус тус консулын байгууллагуудаа нээжээ.

Оросын гадаад бодлогын түүхэнд гол байр суурь эзэлж байсан үе бол Петрийн ба II Екатринагийн үе юм. I Петр хааны үед /1721/ Орос орны нөлөө олон улсын хэмжээнд ихээхэн өсчээ. Энэ үед шинэ Орос орны хилийн хязгаарыг тогтоож, Европын гол гол орнуудад байнгын дипломат төлөөлөгчийн газрын сүлжээг бий болгож, туршлагатай дипломатчдыг илгээж эхэлсэн байна. Тухайлбал: 1699 онд А.А.Матвеевийг Голландад, 1701 онд П.А.Толстойг Туркт элчин сайдаар томилон ажиллуулж байлаа.

Харин II Екатринагийн /1762-1796/ засаглалын үед Орос орны гадаад улс төрийн бодлого болон дипломат алба хүчирхэгжиж, Хар тэнгис, Крымийн орчим /1783/ улмаар Украин, Белорус, Кавказын бүс нутгуудад өөрийн нөлөөг тогтоож чаджээ. Энэ үеийн Оросын дипломат ажиллагааны томоохон амжилтын нэг нь Орос-Туркын дайны /17681774/ төгсгөлд байгуулсан “Кючук-Кайнардын энх тайвны гэрээ” юм.

Ийнхүу хаант Оросын олон улсын харилцаан дахь нэр нөлөө өссөнөөр гадаад бодлого, дипломат ажиллагааг эрхлэн явуулдаг төрөлжсөн албыг өргөтгөж, Европын ихэнх улстай дипломат харилцаа тогтоон гадаад хэргийг эрхлэн явуулдаг албыг өөрчлөн шинэчлэх шаардлага зүй ёсоор гарч иржээ. 
1718-1720 онд “Посольский приказ”-ын суурин дээр Гадаад Хэргийн Коллег /КИД/ байгуулагдсан бөгөөд коллег нь “Улс төрийн департамент” буюу “Нууцын канцелярын газар”, “Олон нийтийн илгээх газар” гэх хоёр нэгжээс бүрдэж байжээ.

“Нууцын канцелярын газар” буюу улс төрийн хэрэг эрхлэх газар нь гадаадын дипломатчдыг хүлээж авах, гадаадад Оросын дипломатчдыг томилох, дипломат баримт бичгийг боловсруулах, үйлдэх мөн илгээх асуудлыг эрхэлдэг байсан бол “Олон нийтийн илгээх газар” нь шуудан харилцааны болон аж ахуйн үйл ажиллагаа мөн түүнчлэн хил орчмоор амьдардаг Орос иргэдийн асуудал гэх мэт бусад асуудлыг зохицуулдаг байв. Орос дахь гадаадын дипломат төлөөлөгчийн газруудын тоо нэмэгдэж, үйл ажиллагаа нь өргөжсөнөөр 1770-аад онд “Ёслолын хэрэг эрхлэх департамент”-ыг байгуулсан бол 1796 онд “Азийн асуудал эрхлэх департамент” байгуулагдсан. Гадаад Хэргийн Коллегийн оршин тогтнож байсан хугацаанд олон арван авъяас билэгтэй дипломатчид төрөн гарч (Г.И.Головкин, Б.И.Куракин, П.П.Шафиров, А.И.Остерман, А.П.Бестужев-Рюмин, Н.И.Панин г.м), цаашдын Оросын дипломат ажиллагааны арга хэлбэр, зарчмуудад онцгой хувь нэмэр оруулжээ. Энэ үед Гадаад Хэргийн Коллег нь гадаад оронд суух консулуудад патент олгож, тангараг өргүүлдэг байжээ.

1802 оны 9-р сарын 8(20)-нд I Александр хааны тушаалаар 8 нэгжээс бүрдсэн Төрийн хэрэг эрхлэх газрыг байгуулсан бөгөөд эдгээр нэгжийн нэг нь Гадаад Хэргийн Яам байжээ. Ийнхүү Гадаад Хэргийн Яамыг байгуулснаар Гадаад Хэргийн Коллегийн үйл ажиллагааг зогсоогоогүй боловч түүний эрх үүргүҮдийг аажмаар ГХЯ-нд шилжүүлэн улмаар 1832 онд Коллегийг татан буулгажээ. ГХЯ-ны анхны сайд нь А.Р.Воронцов байсан бөгөөд тэрээр яамыг улс төрийн асуудал эрхэлсэн 4 нэгжид хуваан зохион байгуулсан бол 1806 онд бүтцэд нь өөрчлөлт оруулж “Консулын хэрэг эрхлэх газар”, “Дорнын хэлний сургалтын хэлтэс”, “Дотоод аж ахуйн нэгж”, “Дотоод асуудал эрхэлсэн департамент, “Гадаад асуудал эрхэлсэн департамент” гэх зэргээр өргөтгөжээ. Гадаад хэргийн сайд нь төрийн хэрэг эрхлэх асуудлаар эзэн хааны дараа орох хэмжээний эрх мэдэлтэй байсан ба түүний туслахаар хоёрын зэрэг ГХЯ-ны төрийн нарийн бичгийн дарга ажиллаж байсан байна.

Тухайн үеийн Оросын дипломатчдын үйл ажиллагааны эрх зүйн үндэс нь 1815 оны Венийн дүрмийн хавсралт болох 1815 оны 3-р сарын 19-нд батлагдсан “Дипломат төлөөлөгчдийн байдал” хэмээх баримт бичиг болж байлаа.

1846 онд К.В.Нессельродын санал болгосны дагуу “Гадаад Хэргийн Яамны эрх зүйн байдал” хэмээх баримт бичиг батлагдсанаар яамны үйл ажиллагааны чиглэл, үүрэг, бүтэц зохион байгуулалт шинэчлэгджээ. 
1832 онд Гадаад Хэргийн Коллегийг татан буулгаснаар Консулын албаны асуудал ГХЯны янз бүрийн хэлтэс газрын эрхлэх асуудалд хамрагддаг болсон. Тухайлбал : дотоод асуудал эрхлэх департамент, аж ахуй тооцооны асуудал эрхэлсэн департамент гэх мэт. 1802 онд Хаант Орос нь 14 Ерөнхий Консулын газар, 8 Консулын газар, 2 Дэд Консулын газартай байсан бол энэ тоо 100 жилийн дараа 29 Ерөнхий Консулын Газар, 69 Консулын Газар мөн Дэд консулын газар 39 болж өргөжсөний зэрэгцээ 300 гаруй Өргөмжит Консулын газрууд бий болсон байв.

1853-1856 оны Крымийн дайны үед Оросын улс төрийн байдал хүндэрсэн. Энэ үед ГХЯыг А.М.Горчаков тэргүүлж байсан ба тэрээр 1859 онд ГХЯ-ны “албан тушаалд томилон ажиллуулах дүрэм"-ийг баталж, 1868 онд ГХЯ-ны бүтэц, зохион байгуулалтыг өөрчилж, 1839 онд 535 байсан албан тушаалын орон тоог 134 болгон цөөлж, үүрэг хариуцлагыг нь нэмэгдүүлсэн байна.

III Александр хааны тушаалаар ГХЯ болон хилийн чанад дахь дипломат төлөөлөгчдийн хоорондын шуудан харилцааны сүлжээг бий болгож 1886 онд дипломат баримт бичгүүдэд гадаад хэлний оронд орос хэлийг хэрэглэх оролдлогыг хийж эхэлжээ. Мөн 19-р зууны хоёрдугаар хагаст Хятад, Япон, Мексик, Марокко, Сиам зэрэг олон улсуудад Оросын дипломат төлөөлөгчийн газрууд байгуулагджээ.

19-р зууны 90-ээд оны үед Оросын гадаад байдал хүндэрсэнтэй холбоотойгоор ГХЯ-ны бүтцэд өөрчлөлт оруулах зайлшгүй шаардлага гарч ирсэн ба 1895 онд яамны зөвлөлийн гишүүн, олон улсын хуульч Ф.Ф.Мартенс баруун Европын орнуудын туршлага дээр тулгуурлан ГХЯ-ыг өөрчлөн байгуулах төлөвлөгөөг боловсруулсан авч энэ нь төдийлөн амжилттай хэрэгжиж чадсангүй. Харин 1906 онд ГХЯ-ны сайдаар А.П.Извольский томилогдсоноор яамны бүтцэд өөрчлөлт оруулж эхэлжээ. Энэ үед яаманд шинээр байгуулагдсан нэгжийн нэг нь “Хэвлэлийн хэлтэс” бөгөөд энэхүү хэлтэс нь тухайн үеийн олон улсын харилцааны асуудлаарх Оросын болон гадаадын хэвлэл мэдээллийн хэрэгслээр нийтлэгдэж байсан илтгэлүүдийг хянаж, яамны үйл ажиллагааны талаар олон нийтэд мэдээлэх үүрэгтэй байжээ.

1913 он гэхэд Оросын хилийн чанад дахь төлөөлөгчийн газрын тоо улам бүр тэлж 47 оронтой дипломат харилцаатай болсон бөгөөд 1758 онд 11, 1868 онд 102, 1897 онд 147, 1903 онд 173 байсан хилийн чанад дахь төлөөлөгчийн газрын тоо 200 гаруй болж өссөн байна.

1917 оны 2-р сарын 17-нд II Николай хааныг түлхэн унагаснаар 2-р сарын 27-нд Түр засгийн газар байгуулагдаж, ГХЯ-ны бүтцийг өөрчлөх тогтоол гарсан бөгөөд “Эдийн 
засгийн”, “Хууль эрх зүйн департамент” болон “Дипломат шифрийн” нэгжийг шинээр бий болгожээ.

1917 оны 10-р сарын 25-26-ны Октябрын хувьсгалын дараагаар Бүх Оросын Зөвлөлүүдийн II Их Хурал хуралдаж, Гадаад Хэргийн Ардын Комиссаруудын Газрыг байгуулан комиссараар Л.Д.Троцкийг сонгосон. ГХАКГ-ын ажилтан, албан хаагчдын тоо 1918 оны 1-р сарын сүүлч гэхэд 200 гаруй болсон ба Зөвлөлтийн анхны дипломатуудыг тухайн үеийн хувьсгалчдаас бүрдүүлж байсан бол өмнөх засаглалын үеийн мэргэжлийн дипломатуудын ихэнх нь Зөвлөлт засгийн газартай хамтран ажиллахаас татгалзсан байна. 1918 оны 4-р сараас ГХАКГ-ыг Г.В.Чичерин толгойлох болжээ.

1922 оны 12-р сарын 30-ны байдлаар Афганистан, Герман, Иран, Монгол, Польш, Турк, Финляндтай дипломат харилцаатай байсан бол Зөвлөлт Орос улсыг де-факто хүлээн зөвшөөрч байсан 6 улс (Норвег, Австри, Чехословак, ДИУ, Итали, Их Британи) Орост янз бүрийн түвшний дипломат болон тусгай төлөөлөгчийн газраа ажиллуулж байжээ. 1924 оны эхээр гадаадын 10 улстай дипломат харилцаатай байсан бол тухайн жилдээ Их Британи, Франц, Италитай, 1925 онд Япон зэрэг улсуудтай дипломат харилцаа тогтоосноор энэ тоо 22 болсон байна. 1925 онд ГХАКГ-ын бүтцийг шинэчилж, бүс нутгийн асуудал эрхэлсэн салбар нэгж мөн эдийн засгийн хэлтсийг бий болгожээ. Энэ бүтэц, зохион байгуулалт нь 1934 он хүртэл хадгалагдсан байна.

1926 оны 1 сарын 8-нд 3ХУ-ын “Консулын журам” батлагдаж, консулын байгууллагууд болох Ерөнхий Консулын Газар, Консулын Газар, Дэд Консулын Газар мөн Консулын Агентуудын тэргүүнүүдэд Консулын патент, экзекватур олгогдож байхаар заажээ.

1930 онд ГХАКГ-ын Комиссараар М.М.Литвинов томилогджээ. Европт болон Алс Дорнодод дайны аюул нүүрлэх болсон энэ үед Оросын дипломатчид хамтын аюулгүй байдлын системийг бий болгох тал дээр томоохон алхмуудыг хийж байсны жишээ нь 1933 онд АНУ-тай дипломат харилцаа тогтоон, 1934 онд Үндэстнүүдийн Холбоонд элссэн явдал юм.

1939 оны 5-р сард Гадаад Хэргийн Ардын Комиссар В.М.Молотов болсон (1939-1949, 1953-1956 онуудад ГХЯ-ны сайдаар тус тус ажиллаж байв) байна. Түүний нэртэй холбоотой ЗХУ-Германы харилцан үл довтлох гэрээний нууц протоколын дагуу Дэлхийн хоёрдугаар дайн эхэлж, 1941 оны 6-р сарын 22-нд Германы арми ЗХУ-ын хилээр халдан довтолсноор ЗХУ-ын гадаад бодлого, дипломат ажиллагаанд томоохон өөрчлөлтийг авчирч өрнийн гүрнүүд тухайлбал АНУ болон Их Британитай харилцаагаа сайжруулах тал дээр ихээхэн өөрчлөлтийг хийсэн байна. Дэлхийн хоёрдугаар дайны 
жилүүдэд Европын бүс нутгийн асуудал эрхэлсэн хэлтсүүдийг шинэчлэх асуудал ГХАКГ-ын хүрээнд хийгдэж байлаа.

1941 онд Зөвлөлтийн дипломат албанд олон улсын жишгийн дагуу Онц бөгөөд Бүрэн эрхт Элчин сайд, Онц бөгөөд Бүрэн эрхт Элчин зэрэг, 1943 онд бусад дипломат ажилтны зэргийг хэрэглэх болсон. Мөн 1943 оноос 1954 оныг хүртэл ГХАКГ болон ГХЧ-ны ажилтнууд тусгай дипломат дүрэмт хувцсаар жигдрэх болжээ.

Дэлхийн II дайнд ялснаар ЗСБНХУ-ын нэр хүнд олон улсын тавцанд ихээхэн өссөн ба үүний нэг илрэл бол Зөвлөлтийн гадаад орнуудтай тогтоосон дипломат харилцаа 1941 онд 28 байсан бол 1945 оны 5 сард гэхэд 41 болтлоо өссөн байна.

1946 оны 3-р сарын 15-нд ГХАКГ-ыг ЗХУ-ын Гадаад Хэргийн Яам болгон өөрчилсөн бол 2-р дайны төгсгөл, НҮБ байгуулагдсан явдал, ҮЧХ-ний өрнөл зэрэг нь ЗХУ-ын ГХЯны бүтцийг өөрчлөн шинэчлэх зайлшгүй шаардлагыг бий болгож Хойд болон Өмнөд Америк, Алс Дорнод, Ойрхи Дорнод, Зүүн Өмнөд Азийн асуудал эрхэлсэн нэгж салбарыг шинээр бий болгожээ. 1950-аад онд ГХЯ-ны бүтцэд оруулсан өөрчлөлт нь 1986 оныг хүртэл хадгалагдаж 1949-1953 оныг хүртэл Гадаад хэргийн сайдаар А.Я.Вышинский, 1957-1985 оныг хүртэл ЗХУ-ын Гадаад хэргийн сайдаар Зөвлөлтийн дипломатч А.А.Громыко нар ажиллаж байлаа.

1980-аад оны дундуур М.С.Горбачев ЗХУ-ын нам төрийн удирдлагад гарч ирснээр олон улсын харилцаанд өөрчлөлт шинэчлэлтийг бий болгож, энэ нь ГХЯ-ны үйл ажиллагаанд тусгалаа олжээ. 1985-1991 оныг хүртэл ЗХУ-ын Гадаад хэргийн сайдаар Э.А.Шеверднадзе ажиллах болсон бөгөөд энэ үеийн Зөвлөлтийн гадаад бодлого нь үзэл сурталжсан байр сууринаас татгалзан олон улсын харилцааны үйл явдалд чиглэсэн, үндэсний ашиг сонирхлыг дээдэлсэн байр сууринд шилжжээ. 1991 оны 11 сард Гадаад Хэргийн Яамыг Гадаад Худалдааны Яамтай нэгтгэн Гадаад Харилцааны Яам болгон өөрчилжээ.

1991 оны 12-р сард ТУХН байгуулагдсанаар ЗХУ-ын хууль эрх зүйн өв залгамжлагч нь Оросын Холбооны Улс болж, Гадаад Харилцааны Яам нь 1992 оны 2 сарын 25-ны ОХУын Ерөнхийлөгчийн зарлигаар ОХУ-ын “Гадаад Хэргийн Яамны түр байдлын тухай”, мөн түүний бүтэц зохион байгуулалтыг шинэчлэх тухай тогтоол баталсан. 1995 оны 3 сарын 14-ний өдрийн зарлигаар ГХЯ-ны үйл ажиллагаа, бүтцийг эцэслэн баталжээ. 1990-1996 оны хооронд А.В.Козырев ОХУ-ын ГХЯ-ыг толгойлж байсан ба энэ үед ГХЯны төв аппарат байнга өөрчлөгдөж, яамны удирдлагатай үзэл санаа нийлээгүй дипломатчид ГХЯ-с шахан зайлуулагдаж байлаа. 1996 онд Гадаад хэргийн сайдаар томилогдсон Е.М.Примаков Оросын гадаад бодлого, дипломат ажиллагаанд томоохон 
өөрчлөлт шинэчлэлтийг хийж эхэлсэн бөгөөд барууны улс төрчид, эрдэмтэд, сэтгүүлчид Оросын гадаад бодлогын нэгэн үе төгсгөл боллоо хэмээн хүлээн авсан юм. 1998-2004 онд мэргэжлийн дипломатч И.С.Иванов Гадаад хэргийн сайдаар ажиллаж байсан бол 2004 оноос өнөөдрийг хүртэл С.В.Лавров ГХЯ-ыг тэргүҮлж байна.

ОХУ-ын Ерөнхийлөгч В.В.Путины 2000 оны 6 сарын 28-ны өдөр баталсан “ОХУ-ын гадаад бодлогын үзэл баримтлал"-аар Ардчилсан Орос орны гадаад бодлогын стратегийн үндэс нь тавигдсан. Түүнчлэн 2004 оны 7 сарын 11-ний өдрийн зарлигаар батлагдсан яамны шинэчилсэн хуулийн дагуу ОХУ-ын ГХЯ-ны бүтэц, зохион байгуулалт мөрдөгдөж байна.

\section{Оросын дипломат албаны онцлог, өнөөгийн бүтэц зохион байгуулалт}

\section{ОХУ-ын Гадаад Хэргийн Яам}

ОХУ-аас олон улсын харилцаанд баримтлах дипломат харилцааны салбарт төрийн үйл ажиллагааг хэрэгжүүлэгч холбооны улсын гол гүйцэтгэх байгууллага бол ГХЯ юм. Үндсэн Хууль болон бусад хууль тогтоомжид заасанчилан Ерөнхийлөгчид олгогдсон эрх мэдлийн хүрээнд ГХЯ түүний шууд удирдлаган дор ажилладаг. ГХЯ нь өөрийн үйл ажиллагаандаa ОХУ-ын Үндсэн Хууль, Холбооны хууль тогтоомж, Ерөнхийлөгчийн зарлиг, Засгийн Газрын тогтоол, захирамж мөн өөрийн дүрмийг тус тус баримтлан ажилладаг. ОХУ-ын ГХЯ-ны сайд, түүний орлогч нар, ерөнхий захирал болон бусад удирдах албан тушаалтнуудаас бүрдсэн ГХЯ-ны Коллеги нь яамны удирдах бүрэлдэхүүн юм. Коллегийн бүрэлдэхүүнийг ГХ-ийн сайдын санал болгосоноор Ерөнхийлөгч баталдаг бөгөөд Коллеги нь ГХЯ-ны үйл ажиллагааны амин чухал асуудлуудыг хэлэлцэн шийдвэр гаргадаг. ЭнэхүҮ шийдвэр нь сайдын тушаалаар хэрэгждэг ба санал зөрөлдсөн тохиолдолд тухайн асуудлыг Ерөнхийлөгчид танилцуулан ГХЯ-ны удирдлага эцсийн шийдвэрийг гаргадаг.

ГХЯ-ны дүрмийн дагуу түүний үндсэн зорилтууд нь дараах маягаар тодорхойлогджээ:

Гадаад бодлогын ерөнхий стратегийг боловсруулах,

Гадаад бодлогын асуудлаарх санал санаачлагыг Ерөнхийлөгчид илтгэн танилцуулж байх,

Гадаад бодлогыг хэрэгжүүлэх, 
Улсын бүрэн эрх, аюулгүй байдал, нутаг дэвсгэрийн бүрэн бүтэн байдлын асуудлаар олон улсын харилцаанд ОХУ-ын ашиг сонирхлыг хамгаалах,

Иргэд болон хуулийн этгээдүүдийн ашиг сонирхлыг хилийн чанадад хамгаалах, Гадаад улс болон ОУБ-тай харилцах харилцааг зохицуулж, түүнд хяналт тавих,

Холбооны улсын бусад байгууллагууд болон холбооны субъектын гадаад харилцаанд баримтлах чиг шугамд тус дэм үзүүлэх.

Эдгээрээс гадна хууль тогтоох байгууллагын (төрийн Дум, Холбооны зөвлөл) гадаад харилцаа, ТББ-уудын гадаад үйл ажиллагаанд туслалцаа дэмжлэг үзүүлж, тэдгээрийн үйл ажиллагааг төрийн гадаад бодлоготой холбох, түүнийг хэрэгжүүлэх нь ГХЯ-ны бас нэгэн зорилт болдог байна.

ГХЯ-аас дээрх зорилтуудыг хэрэгжүүлэхээр явуулдаг үйл ажиллагааных нь зохион байгуулалт, арга барил зэрэг нь бусад улсын ГХЯ-дуудтай үндсэндээ адил юм. Яамыг гадаад хэргийн сайд удирддаг бөгөөд түүнийг үүрэгт ажилд нь томилох, үүрэгт ажлаас нь чөлөөлөх асуудлыг Ерөнхий сайдын санал дээр тулгуурлан Ерөнхийлөгч шийдвэрлэдэг. ГХЯ-ны зорилтуудыг биелүүлэх, түүнийг хэрэгжүүлэх ажлыг гадаад хэргийн сайд хариуцан ажилладаг. Гадаад хэргийн сайдын эрх, үүргүүд:

ОХУ-ыг хоёр болон олон талт харилцаанд төлөөлдөг.

ОХУ-ын олон улсын гэрээ хэлэлцээрт гарын үсэг зурдаг.

Холбооны улсын ба дотоод субъектүүдийн төрийн байгууллагуудтай харилцахад яамаа төлөөлдөг.

Гадаад улсад суух ДТГ-ын болон ОУБ-ын дэргэд суух БТГ-ын тэргүүнийг томилох, чөлөөлөх тухай саналыг өргөн барьдаг.

Гадаад харилцааны асуудлаар Холбооны улсын хэмжээнд даган мөрдөх заавар, дүрэм журмыг олон улсын эрх зүй болон дотоодын холбогдох хууль тогтоомжийн дагуу өөрийн эрх мэдлийн хүрээнд батлан гаргадаг.

2007 оны 9 сарын байдлаар ГХЯ нь бүтцийн хувьд 39 депертамент , 4 салбар байгууллагатай (ОХУ-ын ГХЯ-ны дипломат корпусын аж ахуй-үйлчилгээний удирдах газар, Дипломатын Академи, Москвагийн Их Сургуулийн Олон Улсын Харилцааны Дээд Сургууль, Оросын олон улсын соёл, шинжлэх ухааны хамтын ажиллагааны төв). ГХЯ-ны департаментууд нь үйл ажиллагааныхаа чиглэлээр газар зүйн болон тодорхой чиг үүргийн хэмээн 2 үндсэн хэсэгт хуваагддаг ба департамент болгон 20-30 ажилтантай байлаа.

Оросын Холбооны Улсын Гадаад Хэргийн Яамны бүтэц (2011 оны 4 сарын 1-ний байдлаар) 
Тодорхой чиг Үүргийн департаментууд:

1. Сайдын нарийн бичгийн дарга нарын газар

2. Ерөнхий нарийн бичгийн даргын газар (департамент)

3. Гадаад бодлого төлөвлөлтийн департамент

4. Хэвлэл мэдээллийн департамент

5. Эрх зүйн департамент

6. ТУХН-ийн нэгдүгээр департамент

7. Төрийн ёслолын департамент

8. Эдйн засгийн хамтын ажиллагааны департамент

9. Боловсон хүчний департамент

10. Консулын департамент

11. Хэлний департамент

12. Аюулгүй байдлын департамент

13. Мэдээлэл хангамжийн департамент

14. Дипломат шуудан харилцааны департамент

15. ОХУ-ын холбооны нэгжүүд, парламент, олон нийтийн байгууллагатай харилцах департмент

16. Хилийн чанадад оршин суугаa орос иргэдтэй харилцах департмент

17. Ази-Номхон далайн хамтын ажиллагааны департамент

18. Валют-санхүүгийн департамент

19. Ажил хэргийн удирдах газар (департамент

20. Барилгажилт болон хилийн чанад дахь өмчийн департмент

21. Европын хамтын ажиллагааны департамент

22. Аюулгүй байдал, зэвсэглэл хорогдуулах департамент

23. ТүҮх-баримт бичгийн департамент

24. Олон улсын байгууллагын департамент

25. Хүмүүнлэгийн хамтын ажиллагаа ба хүний эрхийн департамент

26. Шинэээр гарч буй аюул заналын асуудал эрхэлсэн департамент

Салбар байгууллагууд:

1. Москвагийн Их Сургуулийн ОУХДС

2. Дипломатийн Академи

3. Коллеж 
4. адаад хэлний дээд курс

Газар зүйн департаментууд :

• ТУХН-ийн хоёрдугаар департамент (Белорус, Молдав, Украин)

- ТУХН-ийн гуравдугаар департамент (Казакстан, Киргиз, Тажикстан, Турк, Узбекстан)

• $\quad$ ТУХН-ийн дөрөвдүгээр департамент (Азербайжан, Армени, Гүрж)

- Азийн 1-р департамент (Хятад, Хойд Солонгос, Монгол, Өмнөд Солонгос)

- Азийн хоёрдугаар департамент (Афганистан, Бангладеш, Энэтхэг, Иран, Мальдив, Непал, Пакистан, Шри-Ланк)

- $\quad$ Азийн 3-р департамент

- Европын нэгдүгээр департамент (Андорра, Бельги, Ватикан, Итали, Испани, Люксембург, Мальта, Монако, Нидерланд, Португали, Франция)

- Европын хоёрдугаар департамент (Их Британи, Дани Ирланд, Исланд, Латви, Литва, Норвеги, Финланд, Швед, Эстони)

- Европын гуравдугаар департамент (Австри, Унгар, Лихтенштейн, Польш, Словак, ФРГ, Чех, Швейцар)

- Европын дөрөвдүгээр департамент (Албани, Болгар, Босни ба Герцеговин, Грек, Кипр, Македон, Румын, Серби, Словени, Турк, Хорват, Черногор)

- Хойд Америкийн департамент (АНУ, Канад)

• $\quad$ Латин Америкийн департамент (Өмнөд ба Төв Америк)

- Ойрхи Дорнод болон хойд Африкийн департамент (Алжир, Бахрейн, Египет, Израиль, Иордан, Ирак, Йемен, Катар, Кувейт, Ливан, Ливи, Мавритани, Марокко, Арабын Нэгдсэн Эмират, Оман, Палестин, Саудын Араб, Сири, Судан, Тунис)

- $\quad$ Африкийн департамент

ОХУ-ын хилийн чанад дахь төлөөлөгчийн газар

ОХУ нь Зөвлөлтийн үеийн дипломат ажиллагааны үр дүнд бий болсон дэлхийд томоохонд тооцогдох хилийн чанад дахь дипломат байгууллагын сүлжээг эзэмшдэг бөгөөд ОХУ-ын Дипломат төлөөлөгчийн болон Консулын төлөөлөгчийн газар нь Африк, төв Америк, Номхон далайн арлуудын зарим улсуудаас бусад бүх улсад байршиж, үйл ажиллагаагаа явуулдаг.

1991 оны ЗХУ-ын задралын дараа ОХУ нь санхүүгийн асуудлаас шалтгаалан 1992 оноос эхлэн Буркино Фасо, Лесото, Либери, Нигер, Папуа-Шинэ Гвиней, Сан-Томе ба Принсип, Сомали, Суринам, Сьерра-Леон, Того зэрэг улсуудад байсан ДТГ-уудаа хаахад 
хүрчээ. Мөн 2008 оны Гүрж-Осетийн дайны дараа Гүрж улстай дипломат харилцаагаа тасалсан байна.

Хилийн чанад дахь Оросын Дипломат Төлөөлөгчийн Газрууд нь ОХУ-ын Гадаад Харилцааны Яамны удирдлаган дор үйл ажиллагаагаа явуулдаг. ДТГ-уудаа өргөн хүрээнд байгуулах болсон гол шалтгаан нь Хүйтэн дайнаас хойш алдаад байсан нөлөөгөө дахин сэргээх явдал байсан юм. Мөн Ази, Африкийн орнуудад байрлах ДТГуудаараа дамжуулан худалдаа болон бусад харилцаа холбоогоо тус бүсийн орнуудтай хөгжүүлэх зорилготой билээ. Орос улс нь Засгийн газрынхаа шийдвэрийн дагуу ерөнхийлөгчийн зарлигаар дипломат харилцаа тогтоосон улсууддаа элчин сайдын яамдаа байгуулдаг. Венийн конвенц болон олон улсын эрх зүйн дагуу ЭСЯ нь үйл ажиллагаа явуулах бөгөөд ОХУ-ыг суугаа улсдаа элчин сайд нь бүрэн төлөөлнө.

ОХУ нь 2011 оны байдлаар нийт дэлхийн 145 оронд дипломат төлөөлөгчийн газартай бөгөөд эдгээр нь бүгд ЭСЯ-ны зэрэгтэйгээр үйл ажиллагаагаа явуулж байгаагаас Европ тивд - 41, Америк тив - 35, Африк тив - 40, Ази болон Далайн орнууд ба Австрали тивд - 39 тус тус ажиллаж байна.

Мөн 54 улсад 89 Консулын байгууллага ажиллаж байгаагаас 84 Ерөнхий Консулын Газар, 2 Консулын Төлөөлөгчийн Газар, 2 ЭСЯ-ны дэргэдэх Консулын хэлтэс, 1 Төлөөлөгчийн газар тус тус үйл ажиллагаагаа явуулж орос иргэд болон хуулийн этгээдийн эрх ашгийг хилийн чанадад хамгаалан ажиллаж байна. Үүний зэрэгцээ 2008 оны 8 сарын байдлаар 22 ОУБ-ын дэргэд төлөөлөгчөө томилон ажиллуулдагаас 15 бие даасан Байнгын Төлөөлөгчийн Газар ажиллаж, төлөөлөгчийн газрын тэргүүнд Ерөнхийлөгчийн захирамжаар Онц бөгөөд Бүрэн эрхт Элчин сайд, 1-р зэргийн Элчин зэргийг олгодог байна.

ОХУ-д дараах дипломат зэргүүд байдаг . Үүнд:

- $\quad$ Онц бөгөөд бүрэн эрхт элчин сайд

- 1 1-р зэргийн онц бөгөөд бүрэн эрхт элчин

- $\quad$ 2-р зэргийн онц бөгөөд бүрэн эрхт элчин

- $\quad$ 1-р зэргийн элчин зөвлөх

- $\quad$ 2-р зэргийн элчин зөвлөх

- 1-р зэргийн 1-р нарийн бичгийн дарга

- $\quad$ 2-р зэргийн 1-р нарийн бичгийн дарга

- $\quad$ 1-р зэргийн 2-р нарийн бичгийн дарга

- 2-р зэргийн 2-р нарийн бичгийн дарга

- 3-р нарийн бичгийн дарга 
- $\quad$ aтташе

Эх сурвалж :

Ном зохиол:

1.М.Дүгэрсүрэн, О.Хосбаяр “Дипломат ажиллагаа, дипломат албаны үндэс” УБ 1998он

2. Т.В.Зонова “Дипломатия иностранных государств” Москва 2004г.

3. Охотский Е.В. «Дипломатическая служба в системе государственной службы Российской Федерации» М. : РОССПЭН, 2002.

4. Г.Н. Пескова "Замыслы наши, может быть, великие..." К 300-летию Великого посольства Петра I

5.В.И.Попов “Орчин үеийн дипломат ажиллагаa : онол практикийн асуудал” УБ 2007он

6. 4.Ю.В.Сусликов “Новая Россия.Дипломатическая служба”

7.С.Л.Турилова “Из истории архивов внешнеполитического ведомства России 17201802 гг."

Бусад баримт бичгүүд:

1."Независимая газета.”

2.Указ Президента Российской Федерации от 15 октября 1999 г. № 1371 “О порядке присвоения и сохранения дипломатических рангов и об установлении ежемесячной надбавки к должностному окладу за дипломатический ранг”

3. Положение о Министерстве иностранных дел Российской Федерации, утверждённо Указом Президента Российской Федерации от 11 июля 2004 г. № 865

4.Указ Президента Российской Федерации от 11 сентября 2007 года № 1163

5.Федеральный закон Российской Федерации от 27 июля 2010 г. N 205-Ф3 “Об особенностях прохождения федеральной государственной гражданской службы в системе МИД Российской Федерации"

Интернет эх сурвалж :

www.mid.ru

www.wikipedia.ru 
